\title{
Naira Exchange Rate Variation and Nigeria Economic Growth: A Time Series Study
}

\author{
Rev Canon Charles Ugochukwu Okoro, M.Sc. \\ Department of Accountancy \\ Ken Saro-wiwa Polytechnic, Bori \\ Rivers State, Nigeria \\ E-mail:Cuokro50@gmail.com \\ Mrs. Fortune Bella Charles, M.Sc. \\ Department of Banking and Finance \\ Rivers State University, Nkpolu Oroworukwo, Port Harcourt \\ Rivers State, Nigeria
}

\begin{abstract}
This study examined the effect of exchange rate variation on Nigeria economy. The objective was to investigate how Naira exchange rate variations against key currencies affect the country's real gross domestic product. Time series data was sourced from Central Bank of Nigeria statistical bulletin. Real gross domestic products were modeled as the function of United State commodity currency, British commodity currency, Japanese yen currency, Chinese yen currency and French franc currency. The ordinary least square method was used as data analysis techniques. The study used cointegration, unit root, and granger causa lity test and error correction estimate to study the dynamic effects of commodity currencies on financial market. The study found that naira exchange rate variation with the currencies can explain 65 percent variation on Nigerian real gross domestic products while the remaining 35 percent estimation can be traced to external variables not included in the model. The estimated f-test proved that the model is fit while the estimated DW statistics found the presence of positive serial autocorrelation among the variables. The estimated beta coefficient of the variables revealed that commodity currency of US; Japanese yen and Chinese yen have positive and significant effect on Nigeria real gross domestic products while British pound and French Franc have negative effect on Nigeria real gross domestic products. From the co-integration test, we found at least two co-integrating equation from the trace test and maximum eigenvalue. The granger causality test found unidirectional causality from real gross domestic products to Chinese yen and from French Franc to real gross domestic products. The study found that in the long run, Japanese and Chinese yen and French Franc have negative long run effect on Nigeria real gross domestic products; while United States dollar and British Pound Sterling have positive long run effect on Nigeria gross domestic products. The study recommended amongst others that Monetary and macroeconomic policies should be properly articulated with an impregnable feedback loop, implemented to the letter, and a quarterly examination of the impact on the Naira should be regularly engaged, evaluated, interpreted and ensure that the results and possible remedial action $(\mathrm{s})$ get to the appropriate authority timeously so as to ensure well informed decision(s).
\end{abstract}

\section{Keywords: Naira Exchange Rate, Nigeria Economic Growth, US Dollar, British Pound Sterling, Japanese Yen}

\section{Introduction}

The opinion that exchange rate management can be used to influence Nigeria macroeconomic performance can be traced back to 1960 when the country became politically independent, even though the Central Bank of Nigeria and the Federal Ministry of Finance had come into being two years earlier. Ogiogio (1996) stated that the Management of exchange rate can be traced to two divisions/phases; pre-Structural Adjustment era of I960-I985 and post-Structural Adjustment era I986 till date. Central Bank of Nigeria Act 1959 as amended empowered CBN to safeguard the international value of Nigeria currency, by formulating exchange rate policies that will enhance the realization of macroeconomic goals. Nusrate (2008) stated that the exchange rate is one of the most important policy variables, which determines the trade flows, capital flows, foreign direct investment, inflation, international reserve and steady economic growth. Many economies, especially African countries faced crisis in I990s due to miss application and bad choice of exchange rate regime. However, there is no consensus in the theoretical or empirical literature about any unique effect of the exchange rate volatility on macroeconomic indicators. 
The role of exchange rate in any economy is very significant as it directly and indirectly affects domestic price level, profitability of traded goods and services, allocation of resources and investment decisions. Exchange rate movement and exchange rate uncertainty is an important factor which investors take into consideration in their decision to invest abroad (Unugbro, 2007). Foreign capital inflows are generally perceived as something desirable to the industrialized and developing countries. Exchange rate variation increases the risk and the uncertainty of transactions (internally and externally) and predisposes a country to exchange rate related risks. In theory, it is generally agreed that exchange rate fluctuation affects output negatively or positively. According to Aliyu, Yakub, Sanni, and Duke, (2013); it is believed that the negative impact of exchange rate fluctuation may come directly through uncertainty and adjustment costs, and indirectly through its effect on allocation of resources and government policies. While Adeniran, Yusuf and Adeyemi (2014) further informed that variation in exchange rate is an important factor that affects economic performance, due to its impact on macroeconomic variables like outputs, imports, export prices, interest rate and inflation rate. The persistent depreciation in Naira exchange rate has led to a shortage of foreign exchange for the importation of the essential inputs for the industrial sector which has led to high costs of production in the country

The Nigerian government has formulated various exchange rate policies, for instance, fixed parity between the Nigerian pound and the British pound (1960-1967), fixed parity between the Nigerian pound and the American dollar (I9671974), Independent exchange rate policy (1974-I976); Pegging the Naira to an import-weighted basket of currencies (I9761985), market determined exchange rate policy (I986 - Date). The Nigerian fifth exchange rate management commenced during post-SAP era up to date. The first market, SFEM was established with immediate effect in September 26, I986. The Nigerian forex market was liberalized with the introduction of an Autonomous Foreign Exchange Market (AFEM) and the Inter-bank Foreign Exchange Market (IFEM) in 1995 and 1999 respectively. The AFEM metamorphosed into a daily, two-way quote IFEM in October 25, 1999. From 16 July 2002, CBN has replaced IFEM with the Dutch Auction System (DAS) which has been in operation till date. Despite these policies, Nigeria Naira continue to depreciate against key currencies and has this has affected the economy negatively.

The general assumption on the relationship between flexible exchange rate and macroeconomic performance has been that if properly managed and integrated with macroeconomic objectives, it will enhance the realization of macroeconomic goals. However, this assumption is empirical tested and exemplified in the developed economy with greater openness and less import compared to the emerging economies like Nigeria whose import is greater than the export which results in Balance of Payment deficit. Umoru and Odegba (2013) noted that if the exchange rate is not fixed, its behavior should depend on the behavior of the domestic interest relative to the foreign rate. The exact impact of a change in the policy rate is uncertain, because it depends again on the expectations on the interest rates and on domestic and foreign inflation. The relationship between exchange regimes and economic performance of the developing countries like Nigeria has gone beyond theories and principles but focus on the reality of existing impact, for instance the adoption of flexible exchange rate during the Structural Adjustment Programme (SAP) and the depreciating Naira exchange rate against key currencies is expected to affect Nigerian economic performance which has not been captured in existing literature creating a knowledge gap.

However, the relationship between exchange rate regime such as flexible exchange rate and economic performance has been a point of departure among scholars. For instance, the traditional school believe that volatility in exchange rate discourage trade while the portfolio theory believe that volatility in exchange rate creates risk that risk seekers would trade in the mist of volatile exchange rate for profitability objective. This ambiguity has remained unresolved in the emerging economy like Nigeria that deserves investigation. Nigeria over the years has signed multilateral and bilateral trade and investment treaties with various countries apart from United State of America. While there are many studies on the effect of exchange rate on Nigeria economy, the studies focused on Naira exchange rate against the United State Dollar. The neglect of other currencies creates a knowledge gap which this study filled.

\section{Literature Review}

\section{I Exchange Rate Volatility}

Mundell (I968) has brilliantly set out the implications of financial flows and financial markets integration. He demonstrated that, with increasing capital mobility, monetary policy is constrained and sometimes inefficient under fixed exchange rates. The stock of money, which is endogenous, adjusts to the economy. This implies an increased sensitivity of the economy and growth to disturbances. Eichengreen and Hausmann (1999) and Kamil (2006) posit that external exposure may also be explained if developing countries are unable to borrow from foreign financial markets in their own currency, no matter the term of the debt. All long run borrowings (domestic or foreign) must be made in foreign currency. Therefore, external exposure and exchange rate regimes are unconnected. If the principal causes of external exposure are other than the external borrowing in a foreign currency then, a more flexible exchange rate will introduce some exchange rate risk leading economic agents to hedge their foreign currency-positions. This lowers the vulnerability of domestic firms and banks to exchange rate changes and world financial markets disturbances thereby leading to a lower instability in growth rates. Asides from risks related to external exposure; fixed exchange rate regimes often come under speculative attacks. Levy, Yeyati and Sturzenegger (2002) reached the conclusion that 
exchange rate flexibility reduces growth volatility in developing countries; whereas, fixed and intermediate regimes perform better than floats in industrialized countries. Bergwal (2002) simulated the Swedish GDP stability over I974-I994 with different hypotheses about the exchange rate regime. He concluded that the GDP would have been more slightly stable under flexible exchange rates than under the actual adjustable peg which in turn would have clearly dominated an irrevocably pegged exchange rate.

\subsection{Theoretical Frame Work}

\subsection{Purchasing Power Parity (PPP) Theory}

The purchasing power theorem as posit by Kuttner and Posen (2006) assumed that the normal equilibrium rate of exchange existing between two inconvertible currencies is determined by the ratios of their purchasing powers; hence the rate of exchange tends to be established at the point of equality between the purchasing powers of the two currencies. In essence, when one country's inflation rate rises relative to that of another country, decrease exports and increases imports depress the country's currency. The theory attempts to quantify inflation-exchange rate relationship by insisting that changes in exchange rate are caused by the inflation rate differentials. In absolute terms, PPP theory states that the exchange rate between the currencies of two countries equals the ratio between the prices of goods in these countries, implying that exchange rate must change to adjust to the change in the prices of goods in the two countries. According to Kara \& Nelson (2002), the expected inflation differential equals the current spot rate and the expected spot rate differential.

The PPP in its simplest form asserts that in the long run, changes in exchange rate among countries will tend to reflect changes in relative price level. Kamin \& Klau (2003), are of the view that if exchange rates are floating, the observed movement can be explained entirely in terms of changes in relative purchasing power and when it is fixed, equilibrium can be determined by comparing satisfactory methods for:

- Explaining the observed movements in exchange rates for countries whose rates were floating.

- Determining equilibrium parity rates for the countries whose surviving rates were out of line with post war market conditions.

- Assessing the appropriateness of an exchange rate. Grigorianm (2004) opined that despite criticisms of PPP theory, the theoretical foundation and explanation may sound reasonable and acceptable but its practical application in real situation may be an illusion, especially in the long run. $\mathrm{Nucu}$ (20II) however posits that the pitfalls notwithstanding, PPP theory is generally a sine-quo-non in the exchange rate determination literature, and continues to remain relevant in the determination of exchange rate among countries of the world.

\subsubsection{Monetary Theory}

The monetary theory of exchange rate determination is one of the most recent models that have generated lively debate in International Accounting, Economics and Finance; which indeed has made it very popular. The theory is presently the last in the well-known tradition of the monetarists or the monetarist school, which regards money as the major prime move in an economy. Thus the monetary approach, as it is sometimes called, directs attention to the money stock as a primary determinant of the level of exchange rates. Its major thrust is the assertion that exchange rate fluctuations are largely explicable in terms of variations in the relative supplies of national currencies. Within the context of this view point, the monetary approach suggest that the money supply could be used to forecast movement of exchange rates, and that there exists an observable causal relationship between exchange rates and changes in money supply. Levacic and Rebmann (1982) pointed out that by the monetarists model, changes in economic variables affect the exchange rate through their impact on the demand for and supply of money balances. The theory thus stresses the view that the supply of and demand for money are strong forces in determining a country's external position. An increase in the demand for a country's money will lead to surpluses in the balance of payments while an increase in the supply of money, ceteris paribus, will give rise to deficits. According to Ardalan (2003), the monetary approach concerns itself with the deficit on monetary account, which in principle, consists of the items that affect the domestic monetary base. The model emphasizes the monetary aspects of the balance of payments, looks beyond merchandise trade and incorporates the important role of financial assets. In Akpansung (2013), the main thesis of the monetary approach to exchange rates is that a country's exchange rate dynamics is essentially a monetary phenomenon, and that any observed disequilibrium in the balance of payments can be eliminated through an adroit manipulation of monetary variables especially domestic credit, under controlled exchange rate, absence of sterilization by the monetary authorities, and stable demand for money function. This assumption presents the supply of money as endogenous by assuming a feedback from the balance of payments through changes in international reserves to changes in the monetary liabilities of the central bank. Under this approach, money market disequilibrium is seen as a crucial factor provoking balance of payments disequilibrium. Imbalances in the balance of payments will restore equality between the demand for and supply of money in the absence of official intervention. Duasa (20I I) inferred that external disequilibrium is transitory and will self-equilibrate in the long-run.

\subsection{Empirical Review}

Serve'n (2003) examined empirically the link between real exchange- rate uncertainty and private investment in developing countries, using a large cross-country time series data set. The paper builds a GARCH-based measure of real-exchange-rate 
volatility and finds that it has a strong negative effect on investment, after controlling for other standard investment determinants and taking into account their potential endogeneity.

Osinubi and Amaghionyeodiwe (2009) investigated the empirical evidence on the effect of exchange rate volatility on Foreign Direct Investment (FDI) in Nigeria, using secondary time series data from 1970 to 2004. The study utilized the error correction model as well as OLS method of estimation. The results suggest, among others, that exchange rate volatility need not be a source of worry by foreign investors. Also, the study further reveals a significant positive relationship between real inward FDI and exchange rate.

Polodoo, Seetanah and Padachi (20II) examined the impact of exchange rate volatility on the macroeconomic performance of Small Island Developing States (SIDS). Taking a sample of I5 SIDS; the study analyzes econometrically the impact of exchange rate volatility on major macroeconomic variables, namely economic growth, external trade and foreign direct investment on the SIDS. The OLS with robust standard errors results indicate that, exchange rate volatility impacts negatively on current account balance but positively on the growth rate of the economies studied. In a dynamic setting, however, exchange rate volatility does not influence the macroeconomic variables.

Taiwo and Adesola (2013) investigated the impact of unstable exchange rate on bank performance in Nigeria using two proxies for bank performance, namely loan loss to total advances ratio and capital deposit ratio. Government expenditure, interest rate, real gross domestic product were added to exchange rate as independent variables. The two models specified show that the impact of exchange rate on bank performance is sensitive to the type of proxy used for bank performance. Loan loss to total advance ratio shows that fluctuating exchange rate may affect the ability of lenders to manage loans resulting into high level of bad loans while capital deposit ratio does not have significant relationship with exchange rate.

Omorokunwa and Ikponmwosa (20I4) investigated the dynamic relationship between exchange rate volatility and foreign private investment in Nigeria from 1980 to 20II. The finding include among other things that; exchange rate volatility has a very weak effect on the inflow of Foreign Direct Investment (FDI) to Nigeria, both in the long run and in the short run and that exchange rate volatility has a weak effect on foreign portfolio investment in the short run but a strong positive effect in the long run.

Jongbo (2014) examined the impact of real exchange rate fluctuation on industrial output by investigating the effect of misalignment of real exchange rate on the output of the Nigeria industrial sector. The result shows that real exchange rate play a significant role in determining the industrial output. The study further reveals that the capacity utilization ratio is low, the case of which may not be too far away from, partly epileptic power supply, lack of adequate and appropriate technology and so on. Adelowokan, Adesoye and Osisanwo (2015) examined the effect of exchange rate volatility on investment and growth in Nigeria over the period of 1986 to 2014. The results confirm the existence of long run relationship between exchange rate, investment, interest rate, inflation and growth. Finally the results show that exchange rate volatility has a negative effect with investment and growth while exchange rate volatility has a positive relationship with inflation and interest rate in Nigeria.

Jonathan and Kenneth (2016) analyzed the link between exchange rate fluctuations and private domestic investment in Nigeria. The descriptive statistics of the variables included in the model show the existence of wide variations in the variables as depicted by the standard deviation of the exchange rate variable that was unusually high. The findings suggest that, the depreciation of the currency and interest rate does not stimulate private domestic investment activities in Nigeria.

Ikechukwu (2016) investigated the effects of volatility clustering in exchange rate on firm's performance in Nigeria, examining cross sectional data for the most active 20 companies listed on the Nigerian Stock Exchange. The results show that exchange rate fluctuation has significant negative impacts on the rate of return on assets, asset turnover ratio and the portfolio activity and resilience, thus, showing the significant negative impact of exchange rate fluctuation on firm performance in Nigeria between 2004 and 2013.

Umoru and Odjegba (2013) analyzed the relationship between exchange rate misalignment and balance of payments (BOP) mal-adjustment in Nigeria over the sample period of 1973 to 2012 using the vector error correction econometric modeling technique and Granger Causality Tests. The study revealed that exchange rate misalignment exhibited a positive impact on the Nigeria's balance of payments position. The Granger pair-wise causality test result indicated a unidirectional causality running from exchange rate misalignment to balance of payments adjustment in Nigeria at the I percent level. The inconsistency in the research results of the various studies reviewed therefore motivated this study.

Oladipupo and Onotaniyohuwo (20II) investigated the impact of exchange rate on the Nigerian external sector (the balance of payments position) using the ordinary least square (OLS) method for data covering the period between 1970 and 2008. The result revealed that exchange rate has a significant impact on the balance of payment position.

Imoisi (2012) examined the trends in Nigerian's Balance of payments position from 1970-2010 using an econometric analysis. The study carried out a multiple regression analysis using the ordinary least square method for both linear and log linear form. The results showed that the independent variables appeared with the correct sign and thus, conform to economic theory, but the relationship between Balance of payments and inflation rate was not significant. However, the relationship between Balance of payments, Exchange rate and interest rate were significant. 
Unaimikogbo and Enoma (20II) evaluated the effect of monetary policy instruments on balance of payments in Nigeria with a simulation equation model 1986-I997 using ordinary least square estimation technique of data analysis, the study found that both polices contribute significantly to balance of payment. They concluded that monetary variable is more effective and dependable than fiscal variable in affecting changes in economic activities.

Kandil (2004) examined the effects of exchange rate fluctuations on real output growth and price inflation in a sample of twenty-two developing countries. Using theoretical rational expectation model in the analysis and decomposes movements in the exchange rate into anticipated and unanticipated components and concluded that exchange rate depreciation, both anticipated and unanticipated, decreases real output growth and increases price inflation which mean that currency depreciation has a negative effects on economic performance in developing countries.

Mori, Asid, Lily, Mulok and Loganathan (2012) investigated the effects of the exchange rates on economic growth in Malaysia using time series data spanning from I97I to 2009. The results of ARDL bounds test suggest that long-run cointegration exists between both nominal and real exchange rates and economic growth with a significant positive coefficient recorded for real exchange rate and concluded that both exchange rates have a similar causal effect towards economic growth and suggested that a systematic exchange rate via monetary policy should be properly developed to promote the stability and sustainability of economic growth in Malaysia.

Attah-Obeng, Enu, Osei-Gyimah and Opoku (2013) examined the relationship between GDP growth rate and exchange rate in Ghana from the period 1980 to 20I2. The study employed the graphing of the scatter diagram for the two variables which are GDP growth rate and exchange rate, establishes the correlation between GDP growth rate and exchange rate using the Pearson's Product Moment Correlation Coefficient (PPMC) and finally estimates the simple linear regression using OLS. Which confirms to the theory that undervaluation (high exchange rate) stimulates economic growth in the short run. Therefore, policy makers should stabilize monetary and fiscal policies in the long run.

Adeniran, Yusuf and Adeyemi (2014) examined the impact of exchange rate on Nigeria economic growth from 1986 to 2013. Employing the correlation and regression analysis, the ordinary least square (OLS) analyze the data. The result revealed that exchange rate has positive and insignificant impact on Nigeria economic growth and recommended that government should encourage the export promotion strategies in order to maintain a surplus balance of trade and also conducive environment, adequate security, effective fiscal and monetary, as well as infrastructural facilities should be provided so that foreign investors will be attracted to invest in Nigeria.

Akinlo and Lawal (2012) Used Vector Error Correction Model (VECM) examined the impact of exchange rate on industrial production in Nigeria over the period 1986-2010. The finding confirmed the existence of long run relationship between industrial production index and exchange rate, money supply and inflation rate. Moreover, exchange rate depreciation had no perceptible impact on industrial production in the short run but had positive impact in the long run. Output, inflation and exchange rate in Nigeria was the focus of the work by Odusola and

Rasaq (2012) analyzed the impact of exchange rate volatility on Macroeconomic variables. employing Correlation Matrix, Ordinary Least Square (OLS) and Granger Causality test, the findings shows that exchange rate volatility has a positive influence on Gross Domestic Product and suggested that there is need for Nigeria to improve their revenue base in term of increasing number of items meant for export, reduce over reliance on petroleum sector, reduce the importation of non essential items and increased domestic production will reduce the problem caused by exchange rate volatility.

Aliyu (20II) argued that appreciation of exchange rate results in increased imports and reduced export while depreciation would expand export and discourage import. Also, depreciation of exchange rate tends to cause a shift from foreign goods to domestic goods. Hence, it leads to diversion of income from importing countries to countries exporting through a shift in terms of trade, and this tends to have impact on the exporting and importing countries' economic growth. He concluded that appreciation of exchange rate exert positive impact on real economic growth in Nigeria.

Dada and Oyeranti (2012) analysed the impact of exchange rate on macroeconomic aggregates in Nigeria. Based on the annual time series data for the period 1970 to 2009 and employed vector-autoregressive model. The estimation results show that there is no evidence of a strong direct relationship between changes in the exchange rate and GDP growth. Rather, Nigeria's economic growth has been directly affected by fiscal and monetary policies and other economic variables particularly the grow th of exports (oil) and concluded that improvements in exchange rate management are necessary but not adequate to revive the Nigerian economy.

Azeez, Kolapo and Ajayi (2012) also examine the effect of exchange rate volatility on macroeconomic performance in Nigeria from 1986 to 20I0. The model formulated depicts Real GDP as the dependent variable while Exchange Rate (EXR), Balance of Payment (BOP) and Oil Revenue (OREV) are proxied as independent variables. It employs the Ordinary Least Squared (OLS) and Johansen co-integration estimation techniques to test for the short and long runs effects respectively. The results show that oil revenue and balance of payment exert negative effects while exchange rate volatility contributes positively to GDP in the long run. They recommended that the monetary authorities should pursue policies that would curb inflation and ensure stability of exchange rate. 
Ehinomen and Oladipo (2012) examined the impact of exchange rate management on the growth of the manufacturing sector in Nigeria. Ordinary Least Square (OLS) multiple regression analysis was employed to analyzed time-series data which spanned between 1986 to20I0. The empirical result of this study shows that depreciation which forms part of the structural adjustment policy (SAP) 1986, and which dominated the period under review has no significant relationship with the manufacturing's sector productivity. It was found that in Nigeria, exchange rate appreciation has a significant relationship with domestic output and recommended that government should direct its exchange rate management policy towards exchange rate appreciation in order to reduce the cost of production in the manufacturing sector that depends heavily on foreign inputs while there should be total ban of importation on consumer and intermediate goods that can be produced locally.

Yaqub (2010) investigated the effect of exchange rate on output of different sectors in Nigeria. The study adopted the modified IS-LM framework and estimated the behavioural equations. Data on Nigeria from 1970-2007 were utilized. The results obtained indicated that exchange rate had significant contractionary effects on agricultural and manufacturing sectors while it had expansionary effect on services sector. The study therefore concluded that the existing structures in Nigeria could not support an expansionary depreciation argument in the basic sectors during the period of study.

Opaluwa, Umeh and Ameh (2010) examined the impact of exchange rate fluctuations on the Nigerian manufacturing sector during a twenty (20) year period (I986 - 2005). The argument is that fluctuations in exchange rate adversely affect output of the manufacturing sector. This is because Nigerian manufacturing is highly dependent on import of inputs and capital goods. These are paid for in foreign exchange whose rate of exchange is unstable.

\section{Methodology}

This study applies the error correction methodology to a regression model based on the relationship between exchange rate variations on Nigeria economy. The idea is to subject the variables to stationary lest and subsequently remove the nonstationary trends by differencing before regressing. This approach is intended to remove the possibility of spurious regression that may not have considered the problem of unit roots stationarity. As a result, the econometric methodology used in those studies did not account for non-stationarity in the data. The analysis here is primarily based on Engle and Granger (I987), and Engle and Yoo (1987). The idea is to determine the order of integration of the variables, that is, we test whether they are stationary in their levels or whether they have to be differenced once or more before they become stationary. Testing for unit roots is earned by using the Augmented Dickey-Fuller (ADF) test. In order to examine the relationship between the dependent and the independent variables, the model for this study is hereby specified as follows:

$$
\begin{array}{ll}
\mathrm{RGDP}=\alpha_{0}+\beta_{1} U S D+\beta_{2} B P S+\beta_{3} J Y+\beta_{4} C Y++\beta_{4} F F+\text { cí } & \mathrm{I} \\
\text { A-priori, } \mathrm{b},>0, \mathrm{~b}_{3}>0, \mathrm{~b}_{3}>0, \mathrm{~b}_{4}<0, \mathrm{~b}_{5}>0, & 2
\end{array}
$$

Where: RGDP $=$ Real gross domestic products

USD = US dollar proxy by naira exchange rate per dollar

PDS = British pound sterling proxy by naira exchange rate per pound

$\mathrm{YY}=$ Japanese yen proxy by naira exchange rate per yen

$\mathrm{CY}=$ Chinese yen proxy by naira exchange rate per yen

$\mathrm{FF}=$ French francs proxy by naira exchange rate per franc

cí $=$ Error Term

The analysis of short-run dynamics is often done by first eliminating trends in the variables, usually by differencing. The theory of co-integration development in Granger (198I) and elaborated in Engle and Granger (I987) addressed this issue of integrating short-run dynamics with long-run equilibrium. It is important to note that the usual starting point of ECM modeling is to assess the order of integration of both the dependent and independent variables in the model. The order of integration ascertains the number of time a variable will be differentiated to arrive at stationary. Dickey- fuller (DF), Augmented Dickey-Fuller (ADF) and Sargan -Rhargava Durban-Watson (SRDW) are the widely used test for stationary for both individual time series and residual from OLS regressions. Co-integration is based on the properties of the residuals from regression analysis when the series are individually non-stationary. The original co integration regression is specified as follows:

$$
A_{t}=\alpha_{0}+\alpha_{1} \beta_{1}+\ell_{1}
$$

Where A represents the dependent variables, $\beta$ stands for the independent variable, and $\ell_{1}$ is the random error term. $\alpha_{0}$ and $\alpha_{1}$ are intercept and slope coefficients respectively. To include the possibility of bi-directional causality, the reverse specification of equation $I$ is considered. To provide a more defensive answer to the non-stationarity in each time series, the Dickey-Fuller (1979) regression is estimated as follows for a unit root: 


$$
\Delta e_{t}=-\lambda e_{t_{-1}}+W_{t}
$$

If $\mathrm{X}$ Equals zero e is non-stationary. As a result, $\mathrm{A}$ and $\mathrm{B}$ are not co-integrated. In other words, if $\mathrm{X}$ is significantly different from zero A and B is found integrated individually. Given the inherent weakness of the root test to distinguish between the null and the alternative hypothesis, it is desirable that the Augmented Dickey-Fuller (ADF) (I98I) test be applied. The desirability is warranted because it is corrects for any serial correlation by incorporating logged changes of the residuals. To be co-integrated, both A and B must have the same order of integration (Eagle and Granger, 1987 and Granger, I986). The ADF regression is specified as follows:

$$
\Delta e_{t}=\beta_{o} \ell_{t-1}+\sum_{j=i}^{m} \beta_{j} \Delta \ell_{t-1}+\mu_{t}
$$

Where ' $\Delta$ ' the first different operator and ' $\mu$ ' is the new random error term. $M$ is the optimum number of lags needed to obtain "white noise". This is approximated when the DW value approaches 2.0 numerically. The null hypothesis of non-cointegration is rejected, if the estimated ADF statistics is found to be larger than its critical value at I or 5 or I0 per cent level of significance. If $\mathrm{A}$, and $\mathrm{B}$, are found to be co-integrated, then there exist an associated error-correlation Model (ECM), according to Engle and Granger (1987). The usual ECM may take the following form:

$$
\Delta G_{t}=\sigma_{o} e_{t-1}+\sum_{j=1}^{T} \sigma_{1} \Delta A_{t-j}+\sum_{j=1}^{T} \theta_{j} \Delta B_{t-j}+V_{t}
$$

Where $\Delta$ denotes the different operator CM is the error correction term, $T$ is the number of lags necessary to obtain white noise and $\mathrm{V}$, is another random disturbance term. If aoCM is significantly different from zero, then $\mathrm{A}$ and $\mathrm{B}$ have long-R un relationship, the error-correction term $\left(e_{t-1}\right)$ depicts the extent of disequilibrium between A and B The HCM, reveals further that the change in A, not only depends on lagged changes in B, but also on its own lagged changes.

\section{Results and Discussion of Findings}

The following tables contain details of the relationship between Naira exchange rate variation and Nigeria economy between the

\begin{tabular}{|c|c|c|c|c|c|}
\hline Variable & Coefficient & & Std. Error & t-Statistic & Prob. \\
\hline USD & 0.892229 & & I.215909 & 4.733796 & 0.0004 \\
\hline BPS & $-0.7 \mathrm{I} 540 \mathrm{I}$ & & 1.534896 & -3.205487 & 0.0007 \\
\hline JY & 0.331943 & & 0.820052 & 2.404783 & 0.0088 \\
\hline $\mathrm{CY}$ & 0.170058 & & 0.180702 & 0.941096 & 0.3550 \\
\hline $\mathrm{FF}$ & -0.408847 & & 1.074098 & -2.008237 & 0.0035 \\
\hline $\mathrm{C}$ & 28.43707 & & 32.01708 & 0.888184 & 0.3823 \\
\hline R-squared & 0.651992 & Mean dependent var & & & 56.27061 \\
\hline Adjusted R-squared & 0.423565 & S.D. dependent var & & & 23.56958 \\
\hline S.E. of regression & 24.98336 & Akaike info criterion & & & 9.437262 \\
\hline Sum squared resid & I6852.54 & Schwarz criterion & & & 9.709355 \\
\hline Log likelihood & $-\mathrm{I} 49.7 \mathrm{I} 48$ & Hannan-Quinn criter. & & & 9.528813 \\
\hline F-statistic & 4.296157 & Durbin-Watson stat & & & 1.271006 \\
\hline Prob(F-statistic) & 0.000786 & & & & \\
\hline
\end{tabular}
years 2000 to 2017 .

Table I: OLS Regression Results

Source: Computed from E-view

Table II: Presentation of Unit Root Test at First Difference

\begin{tabular}{ccccccccc}
\hline RGDP & -3.667294 & -3.653730 & $-2.957 \mathrm{IIO}$ & -2.617434 & 0.0097 & $\mathrm{I}(\mathrm{I})$ & Reject H0 & Stationary \\
\hline USD & -7.151954 & $-3.66166 \mathrm{I}$ & $-2.9604 \mathrm{II}$ & $-2.619 \mathrm{I} 60$ & 0.0000 & $\mathrm{I}(\mathrm{I})$ & Reject H0 & Stationary \\
\hline BPS & -7.081684 & $-3.689 \mathrm{I} 94$ & -2.971853 & $-2.625 \mathrm{I} 2 \mathrm{I}$ & 0.0000 & $\mathrm{I}(\mathrm{I})$ & Reject H0 & Stationary \\
\hline JY & $-5.130 \mathrm{I} 7 \mathrm{I}$ & $-3.69987 \mathrm{I}$ & -2.976263 & -2.627420 & 0.0003 & $\mathrm{I}(\mathrm{I})$ & Reject H0 & Stationary \\
\hline CY & -8.396422 & $-3.66166 \mathrm{I}$ & $-2.9604 \mathrm{II}$ & $-2.619 \mathrm{I} 60$ & 0.0000 & $\mathrm{I}(\mathrm{I})$ & Reject H0 & Stationary \\
\hline FF & -7.974944 & -3.670170 & -2.963972 & -2.621007 & 0.0000 & $\mathrm{I}(\mathrm{I})$ & Reject H0 & Stationary \\
\hline \multicolumn{7}{c}{ Source: Computed from E-view } \\
\hline
\end{tabular}


Table III: Presentation of Johansen Cointegration Test

\begin{tabular}{ccccc}
\hline Hypothesized & & $\begin{array}{c}\text { Trace } \\
\text { Statistic }\end{array}$ & Critical Value & Prob. \\
\hline No. of CE(s) & Eigenvalue & & & 0.05 \\
\hline None & $0.57897 \mathrm{I}$ & 71.82317 & 95.75366 & 0.6597 \\
\hline At most I & 0.456749 & 45.00649 & 69.81889 & 0.8307 \\
\hline At most 2 & 0.312887 & 26.09077 & 47.85613 & 0.8863 \\
\hline At most 3 & 0.278652 & 14.45782 & 29.79707 & 0.8140 \\
\hline At most 4 & 0.115271 & 4.332186 & 15.49471 & 0.8750 \\
\hline At most 5 & 0.017126 & 0.535503 & 3.841466 & 0.4643 \\
\hline
\end{tabular}

Source: Computed from E-view

Table IV: Error Correction Estimates

\begin{tabular}{|c|c|c|c|c|c|}
\hline Variable & Coefficient & & Std. Error & t-Statistic & Prob. \\
\hline $\mathrm{C}$ & 0.017329 & & 0.007328 & 2.364752 & 0.0330 \\
\hline $\mathrm{D}(\mathrm{RGDP}(-\mathrm{I}))$ & -0.340025 & & 0.301352 & $-I . I 28332$ & 0.2781 \\
\hline $\mathrm{D}(\operatorname{USD}(-\mathrm{I}))$ & 0.001464 & & 0.003147 & 0.465309 & 0.6489 \\
\hline $\mathrm{D}(\operatorname{USD}(-2))$ & 0.001841 & & 0.002820 & 0.652804 & 0.5245 \\
\hline $\mathrm{D}(\operatorname{USD}(-3))$ & 0.000415 & & 0.002699 & 0.153730 & 0.8800 \\
\hline $\mathrm{D}(\mathrm{BPS}(-\mathrm{I}))$ & -0.003355 & & 0.002296 & -1.461154 & 0.1661 \\
\hline $\mathrm{D}(\mathrm{BPS}(-2))$ & -0.004847 & & 0.002195 & -2.208557 & 0.0444 \\
\hline $\mathrm{D}(\mathrm{BPS}(-3))$ & -0.002393 & & 0.002457 & -0.973944 & 0.3466 \\
\hline $\mathrm{D}(\mathrm{JY}(-\mathrm{I}))$ & -0.000673 & & 0.001646 & -0.408716 & 0.6889 \\
\hline $\mathrm{D}(\mathrm{JY}(-2))$ & 0.000344 & & 0.001813 & 0.189519 & 0.8524 \\
\hline $\mathrm{D}(\mathrm{JY}(-3))$ & -0.001042 & & 0.001889 & -0.551348 & 0.5901 \\
\hline $\mathrm{D}(\mathrm{CY}(-\mathrm{I}))$ & 0.000398 & & 0.000314 & 1.266118 & 0.2261 \\
\hline $\mathrm{D}(\mathrm{CY}(-3))$ & -0.000102 & & 0.000234 & -0.436842 & 0.6689 \\
\hline $\mathrm{D}(\mathrm{FF}(-\mathrm{I}))$ & -0.002179 & & 0.003908 & -0.557564 & 0.5859 \\
\hline $\operatorname{ECM}(-\mathrm{I})$ & -0.392257 & & 0.182803 & -2.145787 & 0.0499 \\
\hline R-squared & 0.628270 & Mean dependent var & & & 0.007552 \\
\hline Adjusted R-squared & $0.25654 \mathrm{I}$ & S.D. dependent var & & & 0.039807 \\
\hline S.E. of regression & 0.034323 & Akaike info criterion & & & -3.599735 \\
\hline Sum squared resid & 0.016493 & Schwarz criterion & & & -2.892513 \\
\hline Log likelihood & 67.19615 & Hannan-Quinn criter. & & & -3.378242 \\
\hline F-statistic & 1.690127 & Durbin-Watson stat & & & 2.216982 \\
\hline $\operatorname{Prob}(\mathrm{F}$-statistic $)$ & 0.168753 & & & & \\
\hline
\end{tabular}

Source: Computed from E-view

Table v: Granger Causality Test

\begin{tabular}{lccc}
\hline Null Hypothesis: & Obs & F-Statistic & Prob. \\
\hline USD does not Granger Cause RGDP & $3 \mathrm{I}$ & 0.27576 & 0.7612 \\
\hline RGDP does not Granger Cause USD & & $8.838 \mathrm{II}$ & 0.0012 \\
\hline BPS does not Granger Cause RGDP & $3 \mathrm{I}$ & 0.25225 & 0.7789 \\
\hline RGDP does not Granger Cause BPS & & 0.39938 & 0.6748 \\
\hline JY does not Granger Cause RGDP & $3 \mathrm{I}$ & 0.13728 & 0.8723 \\
\hline RGDP does not Granger Cause JY & & 0.55468 & 0.5809 \\
\hline CY does not Granger Cause RGDP & $3 \mathrm{I}$ & 3.83802 & 0.0346 \\
\hline RGDP does not Granger Cause CY & & $1.9904 \mathrm{I}$ & 0.1569 \\
\hline FF does not Granger Cause RGDP & $3 \mathrm{I}$ & $0.5 \mathrm{I} 37 \mathrm{I}$ & 0.6042 \\
\hline RGDP does not Granger Cause YY & & 2.89661 & 0.0732 \\
\hline
\end{tabular}




\section{Analyses and Discussion of Results}

From the estimated regression model, the results above prove the relationship between the dependent and the independent variables as formulated in the model. The $\mathrm{R}^{2}$ of 0.65 indicate that exchange rate variation against the currencies examined in this study can explained 65 percent variation in Nigerian economic performance while the remaining $35 \%$ is traceable to exogenous variables not captured in the model. This result proved the significance of the model. The Durbin Watson statistics show that there is the presence of serial autocorrelation between the variables in the time series. The regression coefficient proved that flexible Naira exchange rate against US Dollar, Japanese Yen and Chinese Yen has positive and significant effect on Nigerian economy; while British pound sterling and French Franc have negative effect on Nigerian economy as measured by real gross domestic products.

The stationary test on the time series properties of our data were examined by conducting the unit root test using the Augmented Dickey-Fuller (ADF) test and the co-integration test was done using Engle Grange co-integration procedure. In other to estimate the impact of financial intermediation on Nigeria economic development; we tested for the presence of unit root in the panel data set. This was necessitated because we wanted to ensure that the parameters estimated are stationary panel series data. We utilized the Augmented Dickey-Fuller (ADF) to reject the null hypothesis because the data were stationary. The result of the unit root test is presented in table II. It revealed that the data are stationary since the ADF statistical computations are less than the critical values at $1 \%, 5 \%$ and $10 \%$ respectively.

The negative relationship between Naira exchange rate against the British Pound Sterling and French Franc could be traced to the increasing level of Nigerian import from Japan while the positive effect of the American Dollar and the British Pounds Sterling could be trace to the fact that Nigeria is the largest exporter of crude oil to the United States and United States accounts for over $80 \%$ of trade transaction from Nigeria. The positive relationship confirm the findings of Dickson and Andrew (2013) on the negative effect of Nigerian exchange rate depreciation on non-oil export, it is also in line with the findings of Bohara (200I). It also confirms the findings of Cheong et al., (2002) but contrary to the findings of Aristelous (200I).

\section{Conclusion}

Factors that can enhance Naira exchange rate against key currencies has been one of the major challenges facing the Nigerian monetary authorities and macroeconomic policies in the last four decades, this has led to the formulation of various exchange rate policies as well as macroeconomic policies. In less than 20 years Nigeria has over ten exchange rate policies, some are reintroduced after being abolished, for instance the prevailing Dutch Auction System in the Nigerian foreign exchange rate market was first introduced in 1988 after the deregulation of the economy, abolished in the 1990s and reintroduced in 2007. The effects on Nigerian trade relationships cannot be underestimated.

The findings of this study proved that exchange rate variation against the United States Dollar, Japanese and Chinese Yen have positive and significant relationship with Nigerian economic proxy by real gross domestic products; while Naira exchange rate variation against British Pounds Sterling and French Franc have negative relationship with Nigerian economic. The $\mathrm{R}$ square proved that 65 percent variation in Nigerian real gross domestic products can be traced to variation in the Naira exchange rate variation of the currencies examined in the study. The F-statistics indicates that the model formulated is significant in examining the relationship between the dependent and the independent variable. From the above, the study concludes that there is significant relationship between flexible exchange rate variation and Nigerian real gross domestic products.

\section{Recommendation}

- Monetary and macroeconomic policies should be properly articulated with an impregnable feedback loop, implemented to the letter, and a quarterly examination of the impact on the Naira should be regularly engaged, evaluated, interpreted and ensure that the results and possible remedial action(s) get to the appropriate authority timeously so as to ensure well informed decision(s).

- The monetary authority should devise measures of managing the depreciating Naira exchange rate against the British Pounds Sterling and the United States Dollar to enhance a steady growth of the Nigerian economy.

- As a sovereign nation, the need to review her terms of trade with foreign partners - nations and or individuals - has become (not minding our historical ties) imperative; especially when it is counterproductive to our collective wellbeing; which must not be circumvented nor trampled upon.

- The need for the government and its regulatory agencies and system operators in the non-oil sector to work in synergy so as to enable growth in that sector and contribute to the much needed increase in the nation's gross domestic product; cannot be overemphasized. We therefore recommend that a deliberate step by the government of day in conjunction with industry operators and related non-governmental institutions; with the sole objective of developing this sector and ensure its optimal yield; should be engaged.

- The Nigerian Monetary Authorities should develop programmes aimed at identifying and countering any shift in the Naira exchange rate in the international money market. This will help them to be pro-active and give the much needed boost to our ailing economy and stabilize the Naira Exchange Rate at the foreign exchange market. 


\section{References}

Abdallah, A. (2016). Exchange rate variability and manufacturing sector performance in Ghana: evidence from co-integration analysis. International Economics and Business, 2(I), 493-513.

Adelowokan, O.A., Adesoye, A. B. \& Balogun, O.D. (20I5). Exchange rate fluctuation on investment and growth in Nigeria, an empirical analysis. Global Joumal of Management and Business Research: B Economics and Commerce, I5 (IO), $567-$ 582.

Adeniran, J.O., Yusuf, S.A.,\& Adeyemi, O. A. (20I4). The impact of exchange rate fluctuation on the Nigerian economic growth: an empirical investigation. International Journal of Academic Research in Business and Social Sciences, 4(8), $224-234$

Akpansung, A.O. (2013). A review of empirical literature on balance of payment as a monetary phenomenon. Journal of Emerging Trends in Economics and Management Sciences (JETEMS) 4(2), I24-I32.

Aliyu, S., Yakub, M., Sanni, G., \& Duke, O. (2013). Exchange rate pass-through in Nigeria: Evidence from a Vector Error Correction Model. Econ Paper, I07I-IO84.

Attah-Obeng, P, Enu, P., Osei-Gyimah, F.,\& Opoku, C.D. (2013). An econometric analysis of the relationship between gdp growth rate and exchange rate in Ghana. Journal of Economics and sustainable development, 4 (9), I-8

Ayeyemi, L.O. (2013). Industrial development in developing nations: a case study of Nigerian small and medium business enterprises, degree programme in industrial management. Savonia University of Applied Sciences,

Azeez, B.A; Kolopo, F.T \& Ajayi, L.B (2012). Effect of exchange rate volatility on macroeconomic performance in Nigeria. Interdisciplinary Journal of contemporary Research in Business. 4(I), I49 - I55.

Dada, E.A., \& Oyeranti, O.A. (2012). Exchange rate and macroeconomic aggregates in Nigeria. Journal of Economics and Sustainable development, 3(2), 93 - IOI.

Dickey, D.A \&Fuller, W.A (I979). Likelihood ratio statistics for autoregressive time series with a unit root. Econometrica 49, I057-1072.

Igue, N.N \&Ogunleye, T.S. (20I4). Impact of real exchange rate on trade balance in Nigeria. African Development Review, $26(33), 347-358$.

Ikechukwu, K.(2016). Exchange rate fluctuation and firm performance in Nigeria: a dynamic panel regression approach, proceedings of the Australia-middle east conference on business and social sciences 2016, Dubai (in partnership with The Journal of Developing Areas, Tennessee State University.

Ilechukwu, I.N.,\&Nwokoye, E.S. (2015). Long Run Impact of Exchange Rate on Nigeria's Industrial Output. Journal of Economics and Finance, 6(5), 75-86.

Imoisi, A.I. (2012). Trends in Nigerians balance of payments: an empirical analysis from 1970-20I0. European Journal of Business and Management, 4 (2I), 210-2I7.

Jonathan O. E and Kenneth U (2016). The impact of exchange rate fluctuations on private domestic investment performance in Nigeria, Journal of Economics and Finance, 7(3), 07-15.

Jongbo, O. C. (2014). The impact of real exchange rate fluctuations on industrial output in Nigeria. Journal of Policy and Development Studies, $9(I), 268-278$.

Kamin, S. B., \&Klau, dan M. (2003). A multi-country comparison of the linkages between inflation and exchange Rate Competitiveness. International Journal of Finance and Economics, 30(8), 167-184.

Kandil M.(2004). Exchange rate fluctuations and economic activity in developing countries: theory and evidence. Journal of Economic Development. 29 (I).

Kuttner, K. N., \& Posen, A. S. (2006). Inflation, monetary transparency and g3 exchange rate volatility. Peterson Institute Working Paper No. 00-06.

Lawal, E.O. (2016). Effect of exchange rate fluctuations on manufacturing sector output in Nigeria. Journal of Research in Business and Management, 4( IO), 32-39.

Levacic, R., \&Rebmann, A. (I982). Macroeconomics London.Macmillian Publishers Ltd, 89-I00.

Mori, K., Asid, R., Lily, J., Mulok, D., \&Loganathan, N. (20I2). The effects of the exchange rates on economic growth in Malaysia: empirical testing on nominal versus real. IUPJournal of Financial Economics. IO(I), 7-I7

Ndungu, N.S. (1997).Price and exchange rate dynamics in Kenya: An Empirical Investigation(1970-1993).AERC research Paper, 58 .

Nucu .A. E., (201I).Relationship between exchange rate and key macroeconomic indicators. Case Study Romania. The RomanianEconomic Joumal. 25 (8), I27-I45.

Odusola, A.F; \&Akinlo, A.E. (200I). Output, inflation and exchange rate in developing countries: an application to Nigeria. Journal of Development Economics, 39(2), 30I-3I2.

Oladipupo, A. O \&Ogheneov, O. F. (2011). Impact of exchange rate on balance of payment in Nigeria. African Research Reviews, 5 (4), 73-88. 
Omorokunwa, O.G., \&Ikponmwosa, N. (20I4). Exchange rate volatility and foreign private investment in Nigeria. Asian Journal of Business Management, I46-I54.

Opaluwa, D., Umeh, C.,\& Ameh, A. (2010). The effect of exchange rate fluctuations on the Nigerian manufacturing sector. African Journal of Business Management, 4(I4), 2994- 2998.

Osinubi, T S. \&Amaghionyeodiwe, L.A (2009). Foreign direct investment and exchange rate volatility in Nigeria. International Journal of Applied Econometrics and Quantitative Studies, 6(2), I19-127.

Owoeye, T. and Ogunmakin, A.A (2013). Exchange rate fluctuation and bank performance in Nigeria. Asian Economic and Financial Review, 3(2), I78-I85.

Rasaq, A. D. (2012). The impact of exchange rate volatility on the macroeconomic variables in Nigeria. European Scientific Journal,9 (7), I52-I65.

Rohan, W. (200I) Exchange rate exposure and competition: evidence from the automotive industry. Journal of Financial Economics, 5(9), 44I-475.

Serve, N. L (2003). Real-exchange-rate uncertainty and private investment in LDCS. The Review of Economics and Statistics, $85(1), 212-218$.

Umoru, D. \& Odegba, O.P., (2013). Exchange Rate Misalignment and Balance of Payment Adjustment in Nigeria. European Scientific Journal, 9 (13), 260-273.

Unugbro, A.O. (2007). The impact of exchange rate fluctuation on capital inflow: the Nigerian Experience I980 - 2003. The Nigerian Academic forum, I3 (2), I2 - I8.

Yaqub, J.O. (2010). Exchange rate changes and output performance in Nigeria: a sectorial analysis. Pakistan Journal of Social Sciences, 7(5), 12-19.

\section{Copyrights}

Copyright for this article is retained by the author(s), with first publication rights granted to the journal. This is an open-access article distributed under the terms and conditions of the Creative Commons Attribution license (http://creativecommons.org/licenses/by/4.0/). 